\title{
Production of Magnesium Binder Composites Using Local Raw Materials and Technogenic Products
}

\author{
Elvija Namsone \\ Riga Technical University \\ Faculty of Civil Engineering Institute \\ of Materials and Structures \\ Riga, Latvia \\ elvija.namsone@inbox.lv
}

\author{
Genadijs Sahmenko \\ Riga Technical University \\ Faculty of Civil Engineering Institute \\ of Materials and Structures \\ Riga, Latvia \\ genadijs.sahmenko@rtu.lv
}

\author{
Aleksandrs Korjakins \\ Riga Technical University \\ Faculty of Civil Engineering Institute \\ of Materials and Structures \\ Riga, Latvia \\ aleks@latnet.lv
}

\begin{abstract}
Building sector is known as one of the biggest polluters, causing environmental pollution and carbon dioxide emissions, most of which are generated during the production process of building materials. Therefore, researchers and manufacturers have become increasingly interested in environmentally friendly materials with low energy consumption. Magnesium based cements are being studied as an alternative to a widespread material as Portland cement, thus reducing the temperature required for calcination. During this research, magnesium binder-based composites using two types of magnesium (local dolomite waste material and caustic magnesia) were produced. Within the framework of this study, several regimes of thermal treatment were used to produce low carbon dioxide and environmentally friendly magnesium binder composites. Physical, mechanical and thermal properties of obtained specimens were tested.
\end{abstract}

Keywords - magnesium binder composites, magnesiumbased cements, dolomite waste material, magnesium oxychloride cements

\section{INTRODUCTION}

Portland cement is currently one of the most produced and consumed materials in the world, with an average annual amount of production of 4.6 billion metric tons [1] [3]. Building industry has significant impact on environment. About $8 \%$ of the world's anthropogenic carbon dioxide $\left(\mathrm{CO}_{2}\right)$ emissions are related to the cement and concrete industries; cement is responsible for $95 \%$ of the emissions during the production of concrete [1], [4].

Growing concerns excessive $\mathrm{CO}_{2}$ emissions led to proposals for low- $\mathrm{CO}_{2}$ alternative binders [1], [5], [6]. Such binders include magnesium oxide cements which, in combination with other materials, may be used as magnesium oxychloride cements, magnesium phosphate cements, magnesium silicate hydrate cements, etc. [1], [7]

Magnesite $\left(\mathrm{MgCO}_{3}\right)$ calcination is mainly used for the production of magnesium oxide to be used as raw materials of magnesium oxide-based cements [8], [9]. As another source of magnesite serves dolomite $\left(\mathrm{CaMg}\left(\mathrm{CO}_{3}\right)_{2}\right)$ with larger deposits than magnesite [8], [10]. Magnesium oxide (MgO) forms during the calcination process of dolomite ores and dolomite has been already used as raw material to produce MgO-based cement [8], [11], [12]. Currently the most studied magnesium cements are magnesium oxychloride cement (MOC) and magnesium phosphate cement (MPC) [13].

Magnesium phosphate cement is obtained by a chemical reaction between $\mathrm{MgO}$ and soluble acid phosphate. These cements possess vital properties as follows: fast setting, high early strength, excellent fluidity, low shrinkage, high bonding strength, good biocompatibility [8], [14] - [17]. Therefore, MPC have been applied in the following areas: rapid repair, hazardous waste stabilization, biological materials, for the preparation process of foamed concrete and others [8], [13].

Magnesium oxychloride cement, also known as Sorel cement, first was invented in 1867 shortly after the invention of Portland cement [18], [19]. MOC is 
TABLE 1 CONTENT OF DOLOMITE SAMPLES

\begin{tabular}{|l|c|c|}
\hline \multirow{2}{*}{ Content } & \multicolumn{2}{|c|}{ Samples } \\
\cline { 2 - 3 } & LP & LS \\
\hline $\mathrm{CaMg}\left(\mathrm{CO}_{3}\right)_{2}[\%]$ & $92-94$ & $93-95$ \\
\hline $\mathrm{CaCO}_{3}[\%]$ & $2.1-3.6$ & $1.5-2.5$ \\
\hline $\mathrm{SiO}_{2}[\%]$ & other & other \\
\hline
\end{tabular}

obtained by a chemical reaction between $\mathrm{MgO}$ and magnesium chloride $\left(\mathrm{MgCl}_{2}\right)$ solution at ambient temperature, creating ternary system of $\mathrm{MgO}, \mathrm{MgCl}_{2}$ and water [23].

Compared to traditional Portland cement, MOC possesses: light weight, high early strength, good abrasion and corrosion resistance properties, low thermal conductivity [13], [18], [20] - [22]. MOC is widely used at: industrial floor production, grinding wheels. MOC is useful for decorative, fire protection, sound and thermal insulation panels production [18], [19].

Compared to the calcination temperature required for the production of Portland cement, it is many times lower for the production of MOC. Consequently, there is some interest in the construction industry for MOC, because these materials are energy efficiency and has been considered as environmentally friendly [23].

\section{MATERIALS AND METHODS}

\section{A. Used materials}

Magnesium binder compositions were prepared in laboratory conditions. Magnesium oxide (MgO) served as the main component and two types of magnesium were added during the experiment.

Caustic MgO CCM RKMH-F, produced by Austrian company "RHI AG Ltd" with $76 \%$ MgO purity, calcined at $750^{\circ} \mathrm{C}$ and size distribution $90 \%<30 \mu \mathrm{m}$ was used in the first experimental part.

Magnesium, produced from locally available dolomite waste material, obtained from Pḷavinu and Sịlukalns quarries in Latvia, was added in the second part of the research (compositions LP and LS).

TABLE 2 CAUSTIC MAGNESIUM BINDER COMPOSITIONS

\begin{tabular}{|l|c|c|c|c|c|c|}
\hline \multirow{2}{*}{$\begin{array}{c}\text { Components } \\
\text { [weight } \\
\text { proportions] }\end{array}$} & \multicolumn{5}{|c|}{ Magnesium binder compositions } \\
\cline { 2 - 7 } & $\mathbf{T 1}$ & $\mathbf{T 2}$ & $\mathbf{T 3}$ & $\mathbf{T 4}$ & $\mathbf{T 5}$ & $\mathbf{T 6}$ \\
\hline Sand & 2.25 & 2.25 & 2.25 & 2.25 & 2.25 & 2.25 \\
\hline $\mathrm{MgO}$ & 1 & 1 & 1 & 1 & 1 & 1 \\
\hline $\mathrm{MgCl}_{2}$ & 0.75 & 0.63 & 0.50 & 0.75 & 0.63 & 0.50 \\
\hline $\mathrm{H}_{2} \mathrm{O}$ & 0 & 0.25 & 0.38 & 0 & 0.25 & 0.38 \\
\hline
\end{tabular}

\begin{tabular}{|l|c|c|c|c|c|c|}
\hline \multirow{2}{*}{$\begin{array}{c}\text { Components } \\
\text { [weight } \\
\text { proportions] }\end{array}$} & \multicolumn{5}{|c|}{ Magnesium binder compositions } \\
\cline { 2 - 7 } & $\mathbf{T 1}$ & $\mathbf{T}$ & $\mathbf{T 3}$ & $\mathbf{T 4}$ & $\mathbf{T 5}$ & $\mathbf{T 6}$ \\
\hline SF & 0 & 0 & 0 & 0.13 & 0.13 & 0.13 \\
\hline
\end{tabular}

TABLE 3 LIGHTWEIGHT MAGNEISUM BINDER COMPOSITIONS

\begin{tabular}{|l|c|c|}
\hline \multirow{2}{*}{$\begin{array}{c}\text { Components [weight } \\
\text { proportions] }\end{array}$} & \multicolumn{2}{|c|}{$\begin{array}{c}\text { Magnesium binder } \\
\text { compositions }\end{array}$} \\
\cline { 2 - 3 } $\mathrm{MgO}$ & $\lambda \mathbf{1}$ & $\boldsymbol{\lambda 2}$ \\
\hline $\mathrm{MgCl}_{2}$ & 1 & 1 \\
\hline $\mathrm{H}_{2} \mathrm{O}$ & 0 & 0.87 \\
\hline $\mathrm{KP}$ & 0.82 & 0.64 \\
\hline $\mathrm{PB}-\mathrm{LUX}$ & 0.92 & 0.60 \\
\hline
\end{tabular}

To determine CaMg $\left(\mathrm{CO}_{3}\right)_{2}$ and $\mathrm{CaCO}_{3}$ content in the samples with dolomite waste material, mineralogical analysis (XRD or X-ray diffraction analysis) was performed; the results are presented in Table 1. Performing literature review and differential thermal (DTA) and thermogravimetric (TGA) analyses, three regimes of calcination temperature $\left(730^{\circ} \mathrm{C}, 760^{\circ} \mathrm{C}\right.$ and $\left.790^{\circ} \mathrm{C}\right)$ were used.

Magnesium chloride hexahydrate $\mathrm{MgCl}_{2} \cdot 6 \mathrm{H}_{2} \mathrm{O}$ (known as bischofite) containing $47 \% \mathrm{MgCl}_{2}$ served as brine solution and was used at a ratio of 1:1 of mass to water.

Natural, washed sand with fraction size 0-1 mm, supplied by local company "Sakret”, Latvia was added as a filler.

Microsilica or silica fume (SF) has fine particle size in a range from $1 \mu \mathrm{m}$ to $15 \mathrm{~nm}$. SF is pozzolanic additive with complementary cementing properties that helps to improve water resistance and durability of material [1], [24].

\section{B. Magnesium binder compositions}

In the first part of experimental study, magnesium binder compositions using technogenic product - caustic MgO were obtained. Six compositions (T1, T2, T3, T4, T5 and T6) with $\mathrm{MgO} /$ sand ratio 0.44 and containing variable amount of $\mathrm{MgCl}_{2}$, SF and water were produced, see data in Table 2.

Two compositions ( $\lambda 1$ and $\lambda 2$ ) of lightweight magnesium concrete were made. Monopotassium phosphate $\mathrm{KH}_{2} \mathrm{PO}_{4}$ fertiliser (KP) 0-52-35, supplied by "Prayon S.A." and with $\mathrm{P}_{2} \mathrm{O}_{5}$ content of at least $51.6 \%$ was used for hardening of magnesia. Synthetic foaming agent "PB-Lux" was added with a ratio of PB-Lux/MgO 0.92 (data summarized in Table 3).

In the second part of the experimental research, compositions using local dolomite waste material were obtained (LP and LS, adding dolomite waste material from 
Environment. Technology. Resources. Rezekne, Latvia Proceedings of the $13^{\text {th }}$ International Scientific and Practical Conference. Volume 3, 236-241

Pḷaviņu and Sịlukalna quarries, accordingly, see Table 4.) Magnesium oxychloride cement or Sorel cement mixes with three different calcination regimes and water/binder rations 0.4 and 0.35 were prepared.

TABLE 4 COMPOSITIONS USING DOLOMITE WASTE MATERIAL

\begin{tabular}{|c|c|c|}
\hline \multirow{2}{*}{ Properties } & \multicolumn{2}{|c|}{ Magnesium binder compositions } \\
\cline { 2 - 3 } & LP & LS \\
\hline \multirow{2}{*}{$\begin{array}{c}\text { Temperature } \\
\text { of calcination } \\
{\left[{ }^{\circ} \mathrm{C}\right]}\end{array}$} & 730 & 730 \\
\cline { 2 - 3 } & 790 & 760 \\
\hline $\begin{array}{c}\text { Ratio of } \\
\text { water/binder }\end{array}$ & 0.4 & 790 \\
\hline
\end{tabular}

The use of recycled porous glass ceramic aggregates with three particle sizes $(0.63-1.25 \mathrm{~mm}, 1.25-2.5 \mathrm{~mm}$ and 2.5-5.0 mm) resulted in lightweight concrete compositions $(\lambda \mathrm{P}$ and $\lambda \mathrm{S}$ ) with water/binder ratio of 0.45 , see Table 5 .

\section{Testing methods}

To provide the maximum of $\mathrm{MgO}$ phase and the minimum of $\mathrm{CaO}$ phase, calcination of dolomite powder using three temperature regimes of $730^{\circ} \mathrm{C}, 760^{\circ} \mathrm{C}$ and $790^{\circ} \mathrm{C}$ was performed.

In order to obtain a binder powder with a uniform consistency, the calcined dolomite material was subjected to grinding. The process of grinding was done by using planetary ball mill "Retsch PM 400" 220-230 V; 50/60 Hz and rotation speed $300 \mathrm{rpm}$. Fig. 1 presents the obtained material before and after grinding. Dolomite material from Plavinu quarry (LP) was grinded $3.5 \mathrm{~min}$ and grinding time of dolomite from Silukalns quarry (LS) was $5.5 \mathrm{~min}$. The results of grinding fineness are $75.6 \%$ and $76 \%$ (for LP and LS dolomites, respectively).

Universal testing machine "Zwick Z100" with the maximal test force of $100 \mathrm{kN}$ was used to conduct the compressive strength test. The pressure was applied with $0.0005-600 \mathrm{~mm} / \mathrm{min}$ speed. The samples were exposed under relative humidity conditions ( 90-95 \%) and temperature $15-20^{\circ} \mathrm{C}$; the dimensions of the test samples $50 \times 50 \times 50 \mathrm{~mm}$.

TABLE 5 LIGHTWEIGHT MAGNEISUM BINDER COMPOSITIONS

\begin{tabular}{|c|c|c|c|c|c|c|}
\hline \multirow{2}{*}{ Properties } & \multicolumn{5}{|c|}{ Magnesium binder compositions } \\
\cline { 2 - 7 } & \multicolumn{3}{|c|}{$\lambda \boldsymbol{M}$} \\
\hline $\begin{array}{c}\text { Particle } \\
\text { fraction size } \\
{[\mathrm{mm}]}\end{array}$ & $\begin{array}{c}0.63- \\
1.25\end{array}$ & $\begin{array}{c}1.25- \\
2.5\end{array}$ & $\begin{array}{c}2.5- \\
5.0\end{array}$ & $\begin{array}{c}0.63- \\
1.25\end{array}$ & $\begin{array}{c}1.25- \\
2.5\end{array}$ & $\begin{array}{c}2.5- \\
5.0\end{array}$ \\
\hline $\begin{array}{c}\text { The amount } \\
\text { of particles } \\
{[\text { wt\%] }}\end{array}$ & - & - & 100 & - & - & 100 \\
\cline { 2 - 7 } & 20 & 40 & 40 & 20 & 40 & 40 \\
\hline $\begin{array}{c}\text { Bulk density } \\
{\left[\mathrm{kg} / \mathrm{m}^{3}\right]}\end{array}$ & 225 & 186 & 170 & 225 & 186 & 170 \\
\hline
\end{tabular}

\begin{tabular}{|c|c|c|}
\hline \multirow{2}{*}{ Properties } & \multicolumn{2}{|c|}{ Magnesium binder compositions } \\
\cline { 2 - 3 } & $\lambda \boldsymbol{P}$ & $\lambda \boldsymbol{S}$ \\
\hline $\begin{array}{c}\text { Ratio of } \\
\text { water/binder }\end{array}$ & 0.45 & 0.45 \\
\hline
\end{tabular}

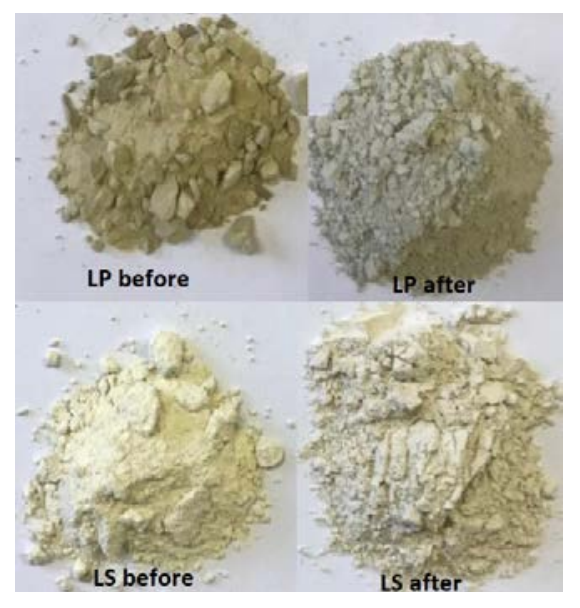

Fig. 1. Dolomite material before and after grinding.

Testing of thermal conductivity was carried out according to guidelines of the LVS EN 12667 standard. It was recorded by equipment for measuring the thermal flow "Laser Comp's FOX 600" with thermal conductivity range 0.01-0.2 W/mK. Testing parameters were determined at $0^{\circ} \mathrm{C}$ for the upper and at $20^{\circ} \mathrm{C}$ for the lower panel.

Specimens-plates were tested in a hardened and dried condition with the following geometry: 300x300x48 mm, $300 \times 300 \times 40 \mathrm{~mm}, 300 \times 300 \times 50 \mathrm{~mm}$ and 300x300x47 mm (for $\lambda 1, \lambda 2$ - compositions being prepared using caustic $\mathrm{MgO}$ and for $\lambda \mathrm{P}$ and $\lambda \mathrm{S}$ - compositions being made adding local dolomite waste material).

\section{RESULTS AND DISCUSSION}

\section{A. Density and compressive strength}

Samples obtained by adding both caustic MgO (compositions T1-T6) and dolomite powder from local quarries (compositions LP and LS) were subjected to a 7day compressive test.

Analysing the results of caustic magnesia compositions, it can be seen that as the amount of $\mathrm{MgCl}_{2}$ decreases, so do the strength values (data presented in Fig.2). For example, reducing the amount of $\mathrm{MgCl}_{2}$ in the compositions $\mathrm{T} 1-\mathrm{T} 3$ by $66 \%$, the compressive strength decreases in the range from 29.5 $\mathrm{MPa}$ to 9.2 $\mathrm{MPa}$. 


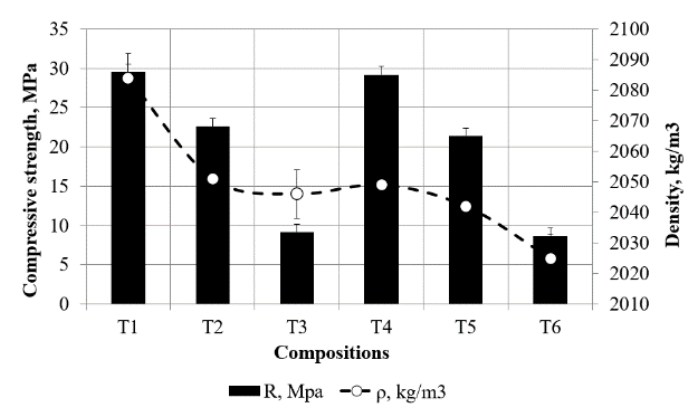

Fig. 2. Results of compressive strength test (using caustic magnesia).

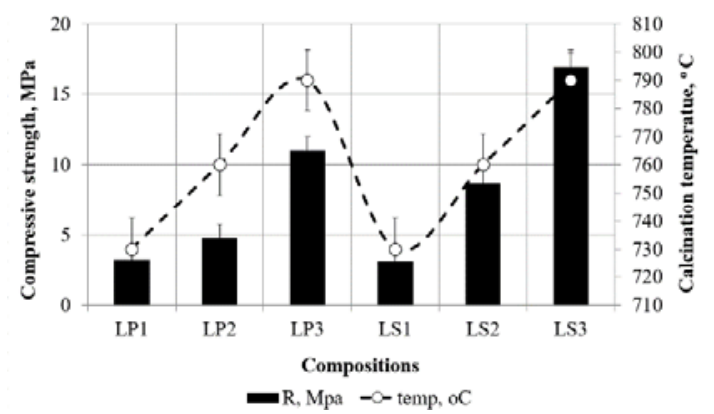

Fig. 3. Results of compressive strength test (using local dolomite waste material)

Summarizing the obtained data from the compositions in the production of which local dolomite powder was added, it can be concluded that the strength values depend on the calcination temperature (data presented in Fig.3). As the calcination temperature increases, the compressive strength also increases.

Maximal compressive strength values of the tested samples were obtained when more magnesium oxide was released during the calcination process. For both series (LP and LS), when dolomite powder from Pḷavinu (LP) and Sillukalns (LS) quarries was added during production, the maximal strength was observed at a temperature of $790^{\circ} \mathrm{C}$ and was $7.73 \mathrm{MPa}$ and $13.82 \mathrm{MPa}$ higher than at $730^{\circ} \mathrm{C}$ calcination.

\section{B. Water/binder ratio - compressive strength}

A following relationship was observed between the water/binder ratio and the compressive strength (the corelation of water/binder ratio and compressive strength is presented in Fig.4): a higher water/binder ratio resulted in lower strength values.

The water/binder ratio increased from 0.25 to 0.45 and the values of compressive strength decreased from 29.5 $\mathrm{MPa}$ to $8.7 \mathrm{MPa}$ when testing the specimens produced using technogenic product (caustic magnesia).

Compositions from local raw material (dolomite powder) included two water/binder ratios 0.4 (LP mixes) and 0.35 (LS mixes); the maximal strength value between LP series samples was 11.0 MPa while it was 17.0 MPa when LS series samples were tested.

\section{Thermal conductivity}

Thermal properties were tested on samples with caustic magnesia and synthetic foaming agent $(\lambda 1, \lambda 2$ compositions) and on samples with dolomite waste material and granulated aggregate (porous ceramics) $(\lambda \mathrm{P}$, $\lambda \mathrm{S}$ compositions), see the results of thermal conductivity test in Fig.5.

Density values of $348 \mathrm{~kg} / \mathrm{m}^{3}$ and $305 \mathrm{~kg} / \mathrm{m}^{3}$ were obtained using synthetic foaming agent $(\lambda 1, \lambda 2)$, but for compositions with porous glass ceramics $(\lambda \mathrm{P}, \lambda \mathrm{S})$ it was about two times higher. With the increase of density values, the coefficient of thermal conductivity also increased. The coefficient was $0.088 \mathrm{~W} / \mathrm{mK}$ and $0.07 \mathrm{~W} / \mathrm{mK}$ for the compositions with technogenic product used (caustic magnesia), and it was $0.115 \mathrm{~W} / \mathrm{mK}$ and

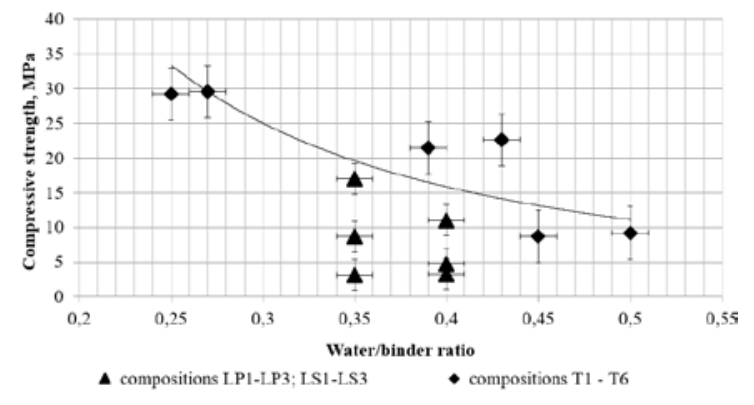

Fig. 4. Corelation of water/binder ratio and compressive strength

$0.097 \mathrm{~W} / \mathrm{mK}$ for the compositions with local raw material (dolomite powder).

Comparing to the results from similar mixes, it can be concluded that the values of coefficient of thermal conductivity decrease with the increase of the amount of $\mathrm{MgCl}_{2}$ (caustic magnesia compositions). When comparing to the data obtained using the porous ceramics of three fractions, it can be seen the results are quite similar: density of $\lambda \mathrm{P}-613 \mathrm{~kg} / \mathrm{m}^{3}$ and of $\lambda \mathrm{S}-600 \mathrm{~kg} / \mathrm{m}^{3}$.

\section{CONCLUSIONS}

In the experimental part of the research, two series of magnesium binder compositions were prepared by using technogenic product (caustic magnesia, produced by "RHI AG”, Austria) with an average density value $2050 \mathrm{~kg} / \mathrm{m}^{3}$ and 7-day compressive strength value 20.1 MPa (values were in the range of 8.7-29.5 MPa); and by using local raw material (dolomite powder from Pḷavinuu and Sịlukalna quarries in Latvia) with the values of 7-day compressive strength 3.27-17.0 MPa.

The results of the research allow to conclude that calcination temperature affects the strength values. Analysing local dolomite powder compositions, it was observed that with the increase of the calcination temperature, when more magnesium oxide is released, the maximal strength values of these samples were obtained. Specimens produced using dolomite from Pḷavinu quarry at calcination temperature $790^{\circ} \mathrm{C}$ showed average strength value 11.0 $\mathrm{MPa}$, but samples using Sịlukalns dolomite material at the same temperature had 7-day compressive 
strength of 17.0 MPa. While testing the prepared specimens with a calcination temperature of $730^{\circ} \mathrm{C}$, about $70 \%$ and $81 \%$ lower compressive strength values were obtained.

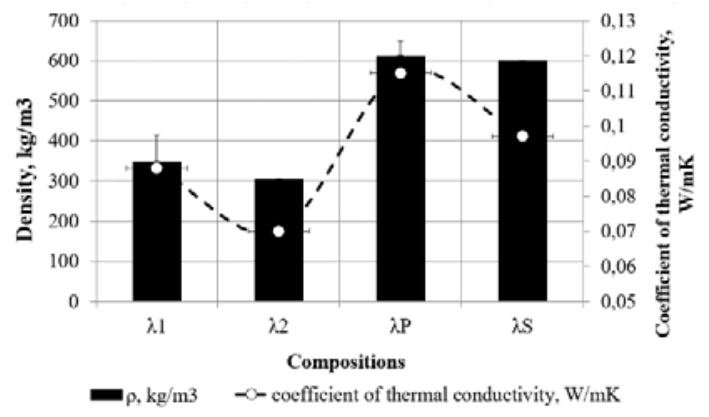

Fig. 5. Results of thermal conductivity test

It was also observed that the amount of magnesium chloride also affects the strength values - as the magnesium chloride content of the mixtures decreased, the compressive strength values also decreased. Addition of 66 $\%$ less magnesium chloride to the compositions resulted in a $70 \%$ reduction in strength values (for the T4-T6 compositions from 29.2 MPa to 8.7 MPa).

The results of the study show that a higher water/binder ratio resulted in lower 7-day compressive strength values. Using caustic magnesia, the tested specimens showed about $70.1 \%$ lower values when increasing water/binder ratio from 0.25 to 0.45 . Using dolomite waste material and increasing the ratio by $13 \%$, an average compressive strength values decreased in a range from 9.6 $\mathrm{MPa}$ to 6.3 MPa.

The use of synthetic foaming agent in the production of lightweight magnesium binder compositions resulted in $43.2 \%$ and $49.2 \%$ lower density values, and in $23.5 \%$ and $28 \%$ lower values of coefficient of thermal conductivity, comparing to the results of the specimens being prepared by adding porous glass ceramics aggregate.

\section{REFERENCES}

[1] A.Pivák, M.Pavlíková, M.Záleská, M.Lojka, O.Jankovský, Z.Pavlík, "Magnesium oxychloride cement composites with silica filler and coal fly ash admixture,” Materials. June 2020; vol. 13(11), p. 2537, doi: $\underline{10.3390 / \mathrm{ma} 13112537}$

[2] K.L.Scrivener, V.M.John, E.M.Gartner, "Eco-efficient cements: potentioal economically viable solutions for a low- $\mathrm{CO}_{2}$ cementbased materials industry,” Cem. Concr. Res., vol.114, pp. 2-26, Dec.2018, https://doi.org/10.1016/j.cemconres.2018.03.015

[3] G.V.P.Bhagatg Singh, K.V.L.Subramaniam, "Production and characterization of low-energy Portland composite cement from post-industrial waste,” J. Clean. Prod., vol. 239, p. 118024, Dec.2019, https://doi.org/10.1016/j.jclepro.2019.118024

[4] N.Lippiatt, T.Ch.Ling, S.Y.Pan, “Towards carbon-neutral construction materials: Carbonation of cement-based materials and the future perspective,” J. Build. Eng., vol. 28, p. 101062, March 2020, https://doi.org/10.1016/j.jobe.2019.101062

[5] J.Gieskam, J.R.Barrett, P.Taylor, "Construction sector views on low carbon building materials,” Build. Res. Inf., vol. 44, pp. 423444, Oct.2015, https://doi.org/10.1080/09613218.2016.1086872

[6] E.Gartner, T.Sui, “Alternative cement clinkers,” Cem. Concr. Res., vol.114, pp. 27-39, Dec.2018, https://doi.org/10.1016/j.cemconres.2017.02.002
[7] L.Wang, L.Chen, J.L.Provis, D.C.W.Tsang, Ch.S.Poon, "Accelerated carbonation of reactive $\mathrm{MgO}$ and Portland cement blends under flowing $\mathrm{CO}_{2}$ gas," Cem. Concr. Compos., vol. 106, p. 103489,

Feb.2020, https://doi.org/10.1016/j.cemconcomp.2019.103489

[8] J.Yu, J.Qian, F.Wang, J.Qin, X.Dai, Ch.You, X.Jia, “Study of using dolomite ores as raw materials to produce magnesium phosphate cement,” Constr. Build. Mater., vol. 253, p. 119147, Aug.2020, https://doi.org/10.1016/j.conbuildmat.2020.119147

[9] A.Sam, J.L.Provics, "Magnesia-based cements: a journey of 150 years, and cements for the future?,” Chem. Rev., vol. 116 (7), pp. 4170-4204, March 2016 https://pubs.acs.org/doi/10.1021/acs.chemrev.5b00463

[10] K.Sasaki, X.H.Qiu, Y.Hosomomi, S.Moriyama, T.Hirajima, "Effect of natural dolomite calcination temperature on sorption of borate onto calcined products,” Micropor. Mesopor. Mater., vol. 171, pp. 1-8, May 2013, https://doi.org/10.1016/j.micromeso.2012.12.029

[11] Z.Z.Liu, S.Wang, J.Huang, Z.H.Wei, B.W.Guan, J.H.Fang, "Experimental investigation on the properties and microstructure of magnesium oxychloride cement prepared with caustic magnesite and dolomite,” Constr. Build. Mater., vol. 85, pp. 247-255, June 2015, https://doi.org/10.1016/j.conbuildmat.2015.01.056

[12] M.Altiner, M.Yildirim, "Study of using dolomite as starting material resource to produce magnesium oxychloride cement,” J. Adv. Concr. Technol., vol 15, pp. 269-277, 2017, https://doi.org/10.3151/jact.15.269

[13] Y.Hao, Y.Li, "Study on preparation and properties of modified magnesium oxychloride cement foam concrete," Constr. Build. Mater., vol. 282 (3), p. 122708, May 2021, https://doi.org/10.1016/j.conbuildmat.2021.122708

[14] B.W.Xu, H.Y.Ma, H.Y.Shao, Z.J.Li, B.Lotchenbach, "Influence of fly ash an compressive strength and micro-characteristics of magnesium potassium phosphate cement mortars," Cem. Concr.

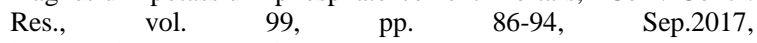
https://doi.org/10.1016/j.cemconres.2017.05.008

[15] Y.Li, B.Chen, "Factors that affect the properties of magnesium phosphate cement,” Constr. Build. Mater., vol. 47, pp. 977-983, Oct.2013, https://doi.org/10.1016/j.conbuildmat.2013.05.103

[16] J.H.Qin, J.S.Qian, C.You, Y.R.Fan, Z.Li, H.T.Wang, "Bond behaviour and interfacial micro-characteristics of magnesium phosphate cement onto old concrete substrate," Constr. Build. Mater., vol. 167, pp. 166-176, Apr.2018, https://doi.org/10.1016/j.conbuildmat.2018.02.018

[17] B.Kanter, A.Vikman, T.Bruckner, M.Schamel, U.Gbureck, A.Ignatius, "Bone regeneration capacity of magnesium phosphate cements in a large animal model,” Acta Biomater., vol. 69, pp. 352361, March 2018, https://doi.org/10.1016/j.actbio.2018.01.035

[18] Ch.Hu, B.Xu, H.Ma, B.Chen, Z.Li, "Micromechanical investigation of magnesium oxychloride cement paste," Constr. Build. Mater., vol. 105, pp. 496-502, Feb.2016, https://doi.org/10.1016/j.conbuildmat.2015.12.182

[19] Z.Li, C.K.Chau, "Influence of molar ratios on properties of magnesium oxychloride cement,” Cem. Concr. Res., vol. 37 (6), pp. 866-870, June 2007, https://doi.org/10.1016/j.cemconres.2007.03.015

[20] R.Siddique, T.R.Naik, "Properties of concrete containing scrap-tire rubber - an overview,” Waste Manage., vol. 24(6), pp. 563-569, 2004, https://doi.org/10.1016/j.wasman.2004.01.006

[21] G.Z.Li, Y.Z.Yu, "Experimental study on urban refuse/magnesium oxuchloride cement compound floor tile,” Cem. Concr. Res., vol. 33(10), pp. 1663-1668, Oct.2003, https://doi.org/10.1016/S00088846(03)00136-4

[22] N.Li, Q.Wang, M.Zhang, "Research on water resistance of magnesium oxychloride cement," Sichuan Cement, vol. 12, pp. 811,2014

[23] L.Wei, Y.Wang, J.Yu, J.Xiao, S.Xu, "Feasibility study of strain hardening magnesium oxychloride cement-based composites," 
Elvija Namsone, et al. Production of Magnesium Binder Composites Using Local Raw Materials and Technogenic Products

Constr. Build. Mater., vol. 165, pp. 750-760, March 2018, https://doi.org/10.1016/j.conbuildmat.2018.01.041

[24] H.Qing, W.Jing, L.Ying, Z.Weixin, C.Chenggong, D.Jinmei, M.Yangyang, Z.A.Yuan, X.Xueying, "The effect of silica fume on the durability of magnesium oxychloride cement," CeramicsSilikaty, 2019, vol. 63(3), pp. 338-346, https://dx.doi.org/10.13168/cs.2019.0029 